\title{
Application of Euphemism in Business Letters Teaching Based on Politeness Principle
}

\author{
Miao Wang \\ Nan Yang Institute of Technology, NanYang 473000, China \\ wmaugust1982@163.com
}

Keywords: politeness principle; business letter; euphemism; application Introduction.

\begin{abstract}
Business letter, as an important media for business people to convey information and exchange ideas, has been extensively applied in the field of international trade and has become an indispensable part of its daily work. The proper use of euphemism, which is an important feature of business letters, can help to achieve effective communication and promote the smooth development of business activities to the greatest degree. This paper aims to study the euphemistic expressions in business letters based on the politeness principle, and then to master the uses of euphemism in business letters based on politeness principle correctly. First, it introduces the politeness principle; then it describes the basic concepts of business letter and euphemism in detail; at last, it analyzes and concludes the linguistic features of euphemisms in business letters from lexical, syntactic and grammatical aspects through examples. By the theoretical introduction and the illustrative analysis, this essay deals with the uses of euphemism in business letters based on politeness principle. The author does hope this essay could contribute to readers' business letter writing.
\end{abstract}

\section{Introduction}

From the current research status at home and abroad, although the study of euphemism has made important progress in different areas, the connection between theory and practice is not close enough. Based on the predecessors, research findings and the specific business letters, this paper analyzes the uses of euphemism in business letters from the perspective of politeness principle. Business letter, as a business communication tool between Chinese and foreign enterprises, plays an important role in Chinese and foreign trade. Whether the letter is polite and euphemistic or not matters to the success and failure of trade. Politeness principle is the basic requirement of business letters. Courteous and euphemistic words can not only help achieve good communication effects and establish good images of foreign trade enterprises, but also create a friendly atmosphere for cooperation of both sides and promote the development of trade activities.

\section{Overview of Politeness Principle}

Cooperative principle is the basic principle of forming language conversations. People in communication have to comply with its several basic rules to form a successful conversation. However, the cooperative principle is not the only conversational principle. Politeness principle is also an important principle people follow during their conversations. As a supplement of the cooperative principle, it can explain different phenomena in the use of language very well. There are a few main theories about politeness principle, such as Leech's politeness norms, the face theory put forward by Brown and Levinson and Lakoff's politeness theory, which complement each other to form a set of relatively complete politeness theory.

\section{Functions of Business Letter}

Business letter is an indispensable part in the process of doing business. It is an important tool for business people to conduct their business by transmitting key messages among business associates, clients, vendors, manufacturers, distributors and others. Most of the ordinary business activities will 
not be possible to be carried on without the business letter. The business letter is so important since it has many functions in business activities.

Firstly, the business letter can help establish business relations. Secondly, the business letter has the function of obtaining and keeping information. Thirdly, the business letter can serve as the settlement of complaints, disputes, claims, and other problems. Fourthly, the business letter can be used to maintain good relationships.

In accordance with L. Sue Baugh, business letters are used to "sell products or services, request material or information, answer customer inquiries, maintain good public relations, and serve a variety of other business functions". (L. Sue Baugh, 1986: 18)Business letters can also serve as part of a companys permanent record. They can be used to verify bookkeeping and inventory entries. Sometimes they can also function as written contracts, which are completely recognized by the courts.

According to Gan Hong, its functions may be: "(1) to ask for or to convey information; (2) to make or to accept offer; (3) to deal with matters concerning negotiation of business." (Gan Hong, 2003: 1)[8]From these functions, it can be clearly seen that business letters are closely related with business affairs and profits within the parties involved in a business transaction

\section{Application of Euphemism in Business Letters Teaching Based on Politeness Principle}

\subsection{Lexical Level}

Lexicon, due to its abundant forms of words and expressions, is one of the most important ways for euphemism to be realized in business letters. A business English letter, as a different type from other literary forms, has its distinguished forms of euphemism which will be illustrated in detail in this part.

\subsection{The Use of Hedges.}

Hedges are the words, which confuse the meanings on purpose. However, this kind of confusion is quite different from ambiguity of words. The characteristics of business letters require clearness in business letter writings and avoiding vague languages and ambiguity, but the hedges really exist in business letters. It is not only understood entirely by the writer and the reader in communication, but also achieves certain communicative function. In business letters, there are many hedges, such as "I'm afraid", "I think", "probably", "it is said" and so on.

[e.g. 7] I'm afraid we can't meet your request and reduce the price to that extent.

This example uses "I'm afraid" before the negative sentence, which makes the tone of refusal not very strong and absolute. The writer not only shows his attitude, but also leaves room for the reader's consideration. It is favorable for both parties to continue negotiation.

The use of hedges in business letters can make the expression more euphemistic, especially for some sensitive topics. If it involves the interests or conflicts of both sides, the hedges can often help alleviate contradictions, avoid conflicts and negotiate circuitously. Therefore, the proper use of hedges with consideration of politeness can not only preserve our own interests, but also save the other party's face. It is beneficial for both parties in business communication.

\subsection{The Use of Negative Words and Phrases.}

Positive words are often used in business letters, but sometimes it is necessary to use negative words instead of positive words to show our views, requests or suggestions politely. This will make the discourse not so subjective and arbitrary and leave more room for negotiation, which is good for both parties to keep favorable cooperation. Then I will give some examples to illustrate this point.

[e.g.10] We are very sorry not to be in a position to accept your order but hope that you will understand our situation.

Cf. We are very sorry to refuse your order but hope that you will understand our situation.

From the above examples, it is not hard to see that the original sentences are in line with the attitude of humility and negotiation to communicate with the other side politely. It is very necessary for the conclusion and performance of contract, and also for maintaining good cooperation in the future. However, the sentences used for comparison show the meaning directly and straightforward, leaving no room for further negotiation. It is bad for the conclusion of transaction and the long-term 
development. Therefore, the use of negative words is an important way in the application of euphemism in business letters.

\subsection{Syntactic level}

Apart from the lexicon, some special sentence patterns can also be employed to realize the euphemism in business letters. This part will introduce two sentence patterns used to express the euphemism in business letters, i.e., the conditional sentence and the interrogative sentence.

The use of conditional sentences in business letters can show politeness and the tone consulting with the reader. It makes the information contained in the main clause has a certain condition, which weakens the meaning that the writer imposes some views on the reader. Therefore, the suggestions or requests sound more tentative and are easy to be accepted by the other party. In the following, I will list some examples to explain this point.

[e.g.13] We shall appreciate it if you will affect shipment as soon as possible.

[e.g.14] We shall be glad if you look into the matter as one of urgency and let us know the reason of this delay.

\subsubsection{Interrogative Sentence.}

In the process of business negotiation, it is often necessary to make it clear about the production, equipment, technologies, products, sales and credit of the other side. For some questions which are improper to ask directly but have to be put forward, the business letters always adopt the interrogative sentences followed by "if I may ask" to show respect and courtesy to the other party.

\subsection{Grammatical level}

In order to avoid the impoliteness caused by the use of some words with subjective meanings in business letters, such as "think", "hope", "be sure" and so on, business people often adopt past tense skillfully to express their utterance politely. The writer uses the past tense to show present requests, wishes and suggestions, making a certain space in terms of the time distance, which actually aims to fully consider the reader's face. It leaves space for achieving a harmonious communication which is good for the establishment of the business and trade relations. Based on this reason, the subjunctive mood formed by the combination of the root forms of other verbs and the modal verbs such as "could", "would", "should" has become another euphemistic expression to show polite requests in business letters. The past tense of verbs used instead of the present sense in business letters makes the utterance politer and expresses a tone of negotiation.

In business letters, the active voice should be used in many cases to show the positions and viewpoints of both sides explicitly. But in other cases, the passive voice is often adopted to make the writing style proper and the tone gentle, especially in the bad-news letters such as letters of complaints, letters of claims and letters of refusals. In light of a certain communication strategy or politeness, the executor of an action is hided to ease the tone and weaken the conflicts. Thus, the passive voice as an effective politeness strategy is widely used in the bad-news business letters.

A lot of "face-threatening" behaviors exist in business letters because both parties inevitably have to put forward suggestions, advice, requests and even commands to the other party on some issues, such as transaction price, shipment, claim, insurance and so on. In order to alleviate the damage to the prestige of each other, the subjunctive mood can be used to express their views, requests and suggestions politely and mildly. The use of the subjunctive mood can help avoid direct and frontal conflicts. It is conducive for both parties to communicate in a harmonious and friendly atmosphere and achieve the desired goals of both sides.

\section{Conclusion}

Business letter, being different from other types of literary forms which require abundant use of rhetorical devices, is a special form of communicative method employed by business people in the field of international trade. An effective business letter undoubtedly requires 7 principles, i.e. completeness, correctness, clarity, courtesy, conciseness, concreteness and consideration. However, it is also of great necessity to employ certain polite and euphemistic expressions since it is different from face-to-face communication. 
In order to accurately grasp the uses of euphemism in business letters based on politeness principle, this thesis mainly analyzes the linguistic features of euphemisms in business letters on the basis of politeness principle and concludes the application of euphemism in business letters from lexical, syntactic and grammatical levels. This paper mainly studies the euphemisms in business letters on the basis of the politeness principle.

\section{Acknowledgements}

This paper is one of the periodical achievements of Innovative Research on International Talent Incubation Path under the "One Belt and One Road" strategy (182400410107), Foreign Trade Flow of Henan Province and Foreign Language Competence Development (2017BYY012).

\section{References}

[1]. Enright,D.J. 1985. Fair of Speech: The Uses of Euphemism [M]. Oxford: Oxford University Press, 29

[2]. Bollinger. 1981. Aspects of Language [M]. Harcourt Bruce Jovanvich. Inc., 148

[3]. Leech,G.N. 1983. Principles of Pragmatics [M]. London:Longman,132

[4]. Baugh. 1986. Handbook for Business Writing [M]. NTC Business Books,18 